\title{
Professor Lord Lister, William Ernest Henley, and Oscar Wilde
}

J H Baron

In December 1888 Oscar Wilde reviewed in Woman's World ${ }^{1}$ W E Henley's A Book of Verses. ${ }^{2}$ Wilde quoted the last 25 lines from In Hospital: XI: Clinical

HIST?

Through the corridor's echoes

Louder and nearer

Comes a great shuffling of feet.

Quick, every one of you,

Straight your quilts, and be decent!

Here's the Professor.

In he comes first

With the bright look we know,

From the broad, white brows the kind eyes

Soothing yet nerving you. Here, at his elbow,

White-capped, white-aproned, the Nurse,

Towel on arm and her inkstand

Fretful with quills.

Here in the ruck, anyhow,

Surging along,

Louts, duffers, exquisites, students, and prigs-

Whiskers and foreheads, scarf-pins and spectacles!-

Hustles the Class! And they ring themselves

Round the first bed, where the Chief

(His dressers and clerks at attention!),

Bends in inspection already.
So shows the ring

Seen, from behind, round a conjurer

Doing his pitch in the street.

High shoulders, low shoulders, broad shoulders, narrow ones,

Round, square, and angular, serry and shove;

While from within a voice,

Gravely and weightily fluent,

Sounds; and then ceases; and suddenly

(Look at the stress of the shoulders!)

Out of a quiver of silence,

Over the hiss of the spray,

Comes a low cry, and the sound

Of breath quick intaken through teeth

Clenched in resolve. And the Master

Breaks from the crowd, and goes,

Wiping his hands,

To the next bed, with his pupils

Flocking and whispering behind him.

\section{Now one can see.}

Case Number One

Sits (rather pale) with his bedclothes

Stripped up, and showing his foot

(Alas for God's Image!)

Swaddled in wet, white lint

Brilliantly hideous with red.

The ward is in the Royal Infirmary, Edinburgh; the chief is Lister, and the patient - Henley. ${ }^{3.8}$

Henley was born in 1849 in Gloucester. His father was a bookseller and printer. One of his four brothers became an actor, another a painter, and a third the keeper of prints in the British Museum. At the age of 12 Henley had developed chronic osteomyelitis (presumably tuberculous) of both ankles. He was given various treatments. His feet were bandaged; his wounds were probed with sticks of caustic; he was even taken to a slaughter house and his foot inserted into the viscera of a freshly killed beast.

At 16 his left leg was amputated below the knee and he learnt to walk with a wooden leg. He had already read avidly. Now he began to write poetry. He moved to London, and lived precariously as a freelance journalist. When he was 23 the infection returned in the other leg and he spent six months in the Royal SeaBathing Infirmary, Margate. The necrosis worsened and amputation was advised. Eight years later he put his recollections into an essay, which was never accepted for publication but parts of which were quoted in the standard biography. ${ }^{6}$ They include pertinent paragraphs on the patient and doctor and patient and patient relationship.

The doctors cared for me and brought me back from the abyss of pain. Among my fellow-patients - just as in myself there was present a feeling of admiration and loyalty towards the doctor who had charge of us. This, I think, forms part of the mental and emotional constitution of those who are sick as opposed to that of those who are well. The regard which the "mystery-man" wins from his patients is vastly increased by 5 his skill and prestige. If only the surgeon be a great surgeon, 8 and possess in an eminent degree the trust of his patients, there is no limit to the confidence which he inspires.

Here I may set down my conclusions as to the general type and tenour of infirmary life. I believe that to anyone, no matter what his habits and associations may be, the entry into hospital is a very painful experience. I believe, too, that to anyone the place becomes not only tolerable but, in a certain limited sense, enjoyable also. With what seemed at first disgustful, he is soon on terms of familiarity and even
The Old Royal Infirmary Edinburgh. After an etching by W $\mathcal{J}$ Hole for the title page of "A Book of Verses" 1888 


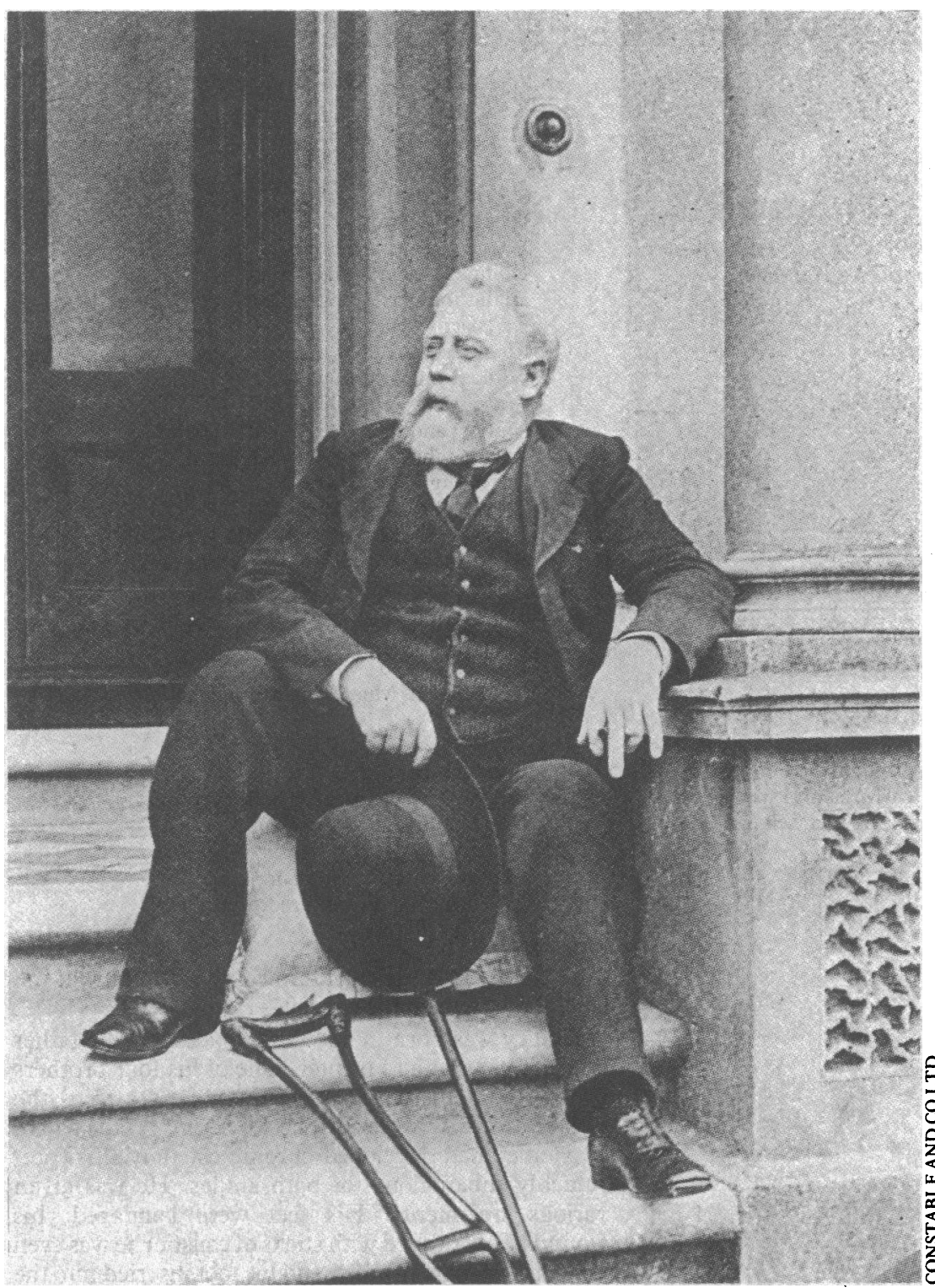

W E Henley, 1899 exploit this grim world. Henley never forgot that the 28 poems in In Hospital were "rejected by every editor of standing in London." No doubt the editors found his realism too shocking for poetry. Nevertheless, a few were accepted by the Cormhill, and its editor Leslie Stephen came to the hospital, bringing with him Robert Louis Stevenson, whose friendship introduced Henley to Edinburgh society and advanced his literary career. Stevenson later used Henley's "maimed masterfulness" as his model for Long John Silver in Treasure Island.

\section{Oscar Wilde}

The Hospital series was finally published in $A B o o k$ of Verses in 1888, and later republished separately. ${ }^{910}$ Nine others were discovered and published in 1936." Henley repaid Lister in The Chief.

His brow spreads large and placid, and his eye,

Is deep and bright, with steady looks that still.

Soft lines of tranquil thought his face fulfil-

His face at once benign and proud and shy.

If envy scout, if ignorance deny,

His faultless patience, his unyielding will,

Beautiful gentleness, and splendid skill,

Innumerable gratitudes reply.

His wise, rare smile is sweet with certainties,

And seems in all his patients to compel

Such love and faith as failure cannot quell.

We hold him for another Herakles,

Battling with custom, prejudice, disease,

At once the son of Zeus with Death and Hell.

Oscar Wilde's was the most enthusiastic review, and his appreciation the one that Henley most cherished. It is often forgotten that Oscar Wilde's father was a distinguished Irish surgeon, Sir William Wilde. Is it fanciful to ascribe some of Oscar Wilde's selective interest in Henley's Hospital poems to his medical ancestry?

Unfortunately, only 18 months later, Henley allowed to appear in his Scots Observer the famous attack on The Picture of Dorian Gray, which began with, "Why go grubbing in muck-heaps?" and ended with, "Mr Wilde has brains, and art, and style; but if he can write for none but outlawed noblemen and perverted telegraph-boys, the sooner he takes to tailoring (or some other decent trade) the better for his own reputation and the public morals."

Wilde's reply is the classical argument against the "absolutely unpardonable crime of trying to confuse the artist with his subject matter... an artist ... has no ethical sympathies at all." And when Henley's daughter died of meningitis in 1894 Wilde wrote his condolences and his advice "to work - to work - that is your duty - that is what remains for natures like ours." Wilde considered Henley the only man who had ever taxed to the full his intellect and ingenuity. Henley said of Wilde, "Clever? I should say he was. Seated where you are he has held the table against me, more than once." to April 1875 in Lister's ward in the Infirmary. The infected bone was laid open and the necrotic area gouged out. The cavity was packed with lint steeped in carbolic acid and allowed to granulate with the leg splinted.

While his foot slowly healed Henley matured. He read widely, including Baudelaire's Fleurs du Mal. He taught himself German, Italian, and Spanish. He met his future wife, Anna Boyle, when she came to see her brother in the next bed. Above all, he wrote and wrote.

\section{Henley's poetry}

Henley began his career as a poet, taking as subject matter his experiences of hospital ward life. He was perhaps the first English poet both to experience and to Black as the pit from pole to pole,

I thank whatever gods may be For my unconquerable soul.
Out of the night that covers me, 
In the fell clutch of circumstance

I have not winced nor cried aloud.

Under the bludgeonings of chance

My head is bloody, but unbowed.

Beyond this place of wrath and tears

Looms but the Horror of the shade,

And yet the menace of the years

Finds, and shall find, me unafraid.

It matters not how strait the gate,

How charged with punishments the scroll,

I am the master of my fate:

I am the captain of my soul.

I am grateful to Constable and Co Ltd for permission to reproduce paragraphs and illustrations from John Connell's WE Henley.

1 Wilde $O$. Henley's poems. The Woman's World 1888;3:108-9. (Reprinted in: Lucas EV, ed. A critic in Pall Mall being extracts from reviews and miscellanies by Oscar Wilde. London: Methuen, 1919:123-9.)

2 by Oscar Wilde. London: Methuen, 1919:123-9.) 1888.

3 Cornford LC. William Emest Henley. London: Constable, 1913.

4 Williamson K. W E Henley: a memoir. London: Harold Shaylor, 1930.

5 Buckley JH. William Emest Henley: a study in the "counter-decadence" of the 'nineties. Princeton: University Press, 1945.

6 Connell J (pseudonym of Robertson JH). W E Henley. London: Constable, 1949.

7 Baron JH. Captain of his soul. Medical News 1965;133:18.

8 Goldman M. Lister ward. Bristol: Adam Hilger, 1987.

9 Henley WE. In hospital. The Bibelot: VII (1). Portland: Thomas Mosher, 1901.

10 Henley WE. In hospital: rhymes and rhythms. Portland: Thomas Mosher, 1903.

11 Roudin MB, Moschowitz E. The unpublished poems of "In Hospital" by William Ernest Henley. Bull Inst Hist Med 1936;4:231-41.

\section{British medical services at the Battle of Waterloo}

\section{R Howard}

By the morning of 18 June 1815 Wellington had concentrated 67000 men and 156 guns on the ridge of Mont-St-Jean in front of the village of Waterloo. The French army of 72000 men and 246 guns massed on the heights of La Belle Alliance 1400 yards south of the allies. ${ }^{1}$ Napoleon's tactics at Waterloo have variously been attributed to fatigue, overconfidence, and ill health. As Wellington wrote, "He did not manoeuvre at all. He just moved forward in the old style and was driven off in the old style." With the arrival of the Prussians on the French right flank at about $800 \mathrm{pm}$ Wellington counterattacked and Napoleon's last army disintegrated. In the space of about six square miles lay more than 52000 dead and wounded. About 6700 were Prussians, 15000 were from the allied army, and the rest were French.

So how were the British army medical services organised to meet the demands of such a conflict? There is little in the way of official documentation so our knowledge is dependent on numerous fragmentary sources. Essentially the medical services could be divided into three parts: army medical department; ordnance medical department (for the artillery); separate establishment for the household troops.

The army medical department was itself divisible into three: the administrative officers, the hospital or medical staff, and the regimental medical organisation. $^{3}$

Such background information is necessary to unravel the way in which the medical services functioned during the battle itself. We can probably summarise as follows. When a soldier fell wounded on the field it was

Malmesbury, Wiltshire SN16 0BE

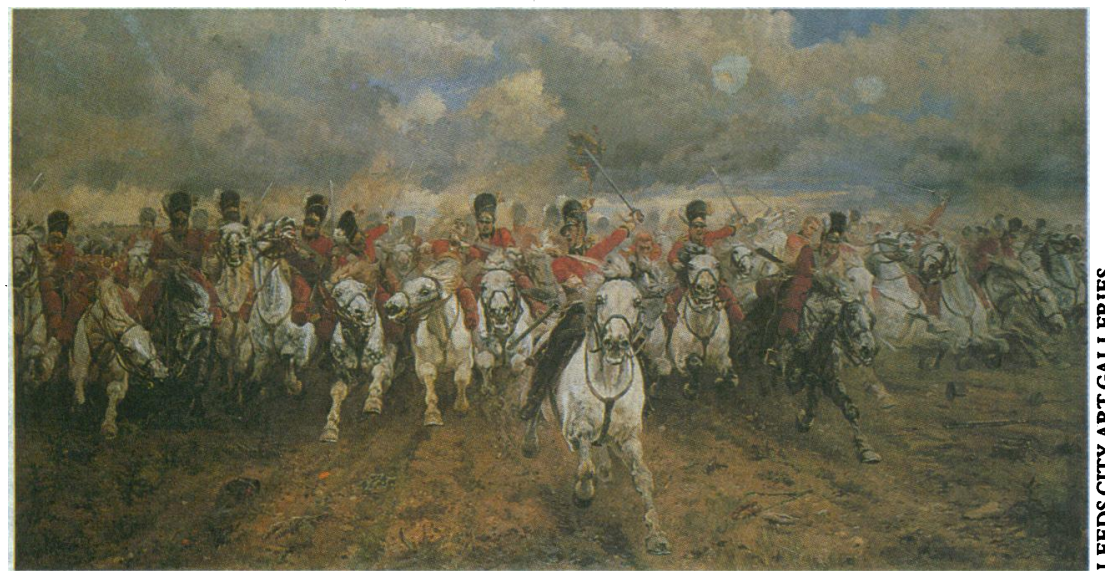

"Scotland for Ever." Lady Butler's dramatic portrayal of the charge of the Scots Greys. quite likely that no help would be forthcoming. If he was lucky, however, either his colleagues or bandsmen would carry him back to receive medical care from the regimental surgeons. There was no equivalent to the flying ambulance of the French instituted by Larrey ${ }^{4}$ and it has been estimated that at Waterloo 12000 men were absent having gone to the rear with the wounded.

Early in the battle this first line medical help was provided in brigade dressing stations situated just behind the ridge. As hostilities progressed regimental medical officers were directed to fall back to the temporary hospitals in the houses of Mont-St-Jean and Waterloo and in other buildings behind the line. The wounded reached these facilities either on foot, by stretcher, in country carts, or in the wagons of the royal wagon train. The medical staff were employed at headquarters, along the lines of communication, and in the general and field hospitals. We are told by Howell that a field hospital was opened at Mont-St-Jean three days after the battle. Several general hospitals were in the process of formation at Brussels, Antwerp, Ghent, Bruges, and Ostend. There is little doubt that the medical personnel were overwhelmed by the magnitude of the casualties.

\section{Accounts of the battle}

On the night before the hostilities a huge downpour occurred and most of the regimental surgeons were understandably more concerned with immediate comforts than with the likely toils of the following day. Covered in thick mud, Assistant Surgeon James of the 1st Life Guards, felt himself lucky to find warmth and shelter in a small cottage. ${ }^{5}$ Another assistant surgeon, John Smith, of the 12th Light Dragoons eventually fell asleep in a drain by the roadside, and as the night wore on the water gradually rose through his bundle of straw until he seemed to be lying at the bottom of a leaky boat. ${ }^{6}$

The ferocity of the fighting next day is well detailed in many memoirs. John Kincaid of the 95th Rifles, a veteran of the Peninsular War, thought that this might be the first battle in which everybody was killed. It is with a certain relish that he relates the tale of two doctors of his brigade who set up their post behind a high, bushy tree. Early in the battle a round shot cut the tree in two and it fell on their heads. Fortunately, only dignity was damaged.?

Assistant Surgeon Gibney wrote, "At first the medical officers remained at the positions occupied by 